\title{
INCIDENCE OF AEROMONAS SPECIES IN RAW MILK AND SOME DAIRY PRODUCTS IN KAFR EL-SHEIKH CITY AND GROWTH CHARACTERISTICS OF AEROMONAS HYDROPHILA IN YOGHURT
}

\author{
Azza, M.M. Deeb \\ Department of Food Hygiene, Faculty of Veterinary Medicine, Kafr El-Sheikh, \\ Tanta University
}

\begin{abstract}
75 random samples of raw milk, yoghurt and cooking butter (25 of each) were collected from different localities, in Kafr El-Sheikh city, to be examined for the presence and any countable population of Aeromonas species. Aeromonas species could be isolated from 8\%, $44 \%$ and $36 \%$ from raw milk, yoghurt and cooking butter by direct plate surface technique while could be isolated from 12, 44 and $48 \%$ of the examined sample by using enrichment broth medium. A. hydrophila could by isolated from 4\%, 24\% and $16 \%$ of raw milk, yoghurt and cooking butter, A. caviae could isolated form 4, 24 and $24 \%$, A. sobria could be isolated form $12 \%$ of examined yoghurt samples only, $\boldsymbol{A}$. trota could be isolated from $8 \%$ of each raw milk \& yoghurt samples while 4\% from cooking butter, A. janda could be isolated from $4 \%$ of examined raw milk samples only and $\boldsymbol{A}$. schuberttii could be isolated from $4 \%$ of examined yoghurt samples.
\end{abstract}

The $\mathrm{pH}$ of yoghurt has significant effect on growth of aeromonas hydrophila as the $\mathrm{pH}$ decrease. The count of $\mathrm{A}$. hydrophila decrease and the organism is completely inhibited as the $\mathrm{pH}$ reach 3.9.

\section{INTRODUCTION}

Aeromonas are ubiquitous inhabitants of natural waters, both fresh and salt, where they infect animals. In humans, they are most often associated with infections of wounds acquired near or in water or with diarrheal disease (Janda, 1991). 
Five diarrhea presentations for aeromonas-related gastroenteritis: Secretory (acute watery diarrhoea, often with vomiting), dysenteric (accompanied by blood and mucus in the stool), chronic (lasting longer than 10 days), choleric ("rice water" stools), and traveler's (Janda and Duffey, 1988).

Aeromonas-hydrophila produces a heat-labile enterotoxin and a heat-stable cytotoxic enterotoxin. Adherence mediated by pili may also serve as a virulence factor (Janda, 1991 and Junda \& Duffey, 1988).

Besides its increasing concern as a food borne pathogen, A. hydrophila could play an important role in deterioration of food stored at refrigeration temperature because of its ability to grow and produce extracellular enzymes (lipase, protease, amylase and nuclease) at low temperature (Beuchat, 1991).

Isolation of Aeromonas spp. has been reported from raw milk, butter, yoghurt, soft cheese and ice cream (Freitas et al., 1993; Khalil, 1997; Abd El-Hady and Halawa, 1999 and El-Shorbagy and AlGanzoury, 2002).

The goal of the present investigation is to estimate the prevalence of Aeromonas species in raw milk, yoghurt and cooking butter in Kafr ElSheikh city.

\section{MATERIAL AND METHODS}

\section{Collection of samples:}

Seventy five random samples(25 raw milk, 25 yoghurt and 25 cooking butter)were collected from different dairy shops and groceries in Kafr ElSheikh city. Collected samples were transferred to the laboratory with a minimum of delay for sanitary, chemical and microbiological examinations.

\section{Preparation of samples:}

Samples were prepared as the technique described by $\boldsymbol{A P H A}$ (1992). 


\section{Sanitary examination:}
A) Determination of titratable acidity of milk (A.P.H.A., 1985).
B) Determination of pH values of yoghurt.

The $\mathrm{pH}$ values of yoghurt samples were measured by $\mathrm{pH}$ meter (Jenway, $3505 \mathrm{pH}$ meter).

\section{Determination of sodium chloride content of Butter (ISO 1738- 1980).}

\section{Microbiological examination:}

A) Preparation of serial dilution (A.P.H.A., 1992):

B) Enumeration of Aeromonas spp.:

a- $100 \mu \mathrm{l}$ from each dilution were evenly spread onto pre-poured plates of aeromonas selective agar (Oxoid) and incubated at $30^{\circ} \mathrm{C} / 24 \mathrm{hrs}$. The presumptive plates were counted and calculated.

b- Isolation and confirmation of Aeromonas spp. by using enrichment broth medium. $25 \mathrm{ml}$ or $\mathrm{g}$. of each sample were added to $225 \mathrm{ml}$ of Ampicillin broth (TSB plus $30 \mathrm{mg} / \mathrm{L}$ ampicillin) and incubated at $30^{\circ} \mathrm{C}$ for $24 \mathrm{hrs}$. (APHA, 1992). Five colonies presumed to be Aeromonas were streaked onto tryptone soya agar (TSA) slants, incubated at $30^{\circ} \mathrm{C} / 24 \mathrm{hrs}$. for complete confirmation according to (Popoff, 1984).

\section{Survival of Aeromonas hydrophilia in yoghurt:}

\section{A) Bacterial strains:}

1. A mixture of active culture of Streptococcus thermophillus (14486) and Lactobacillus bulgaricus (11842); (1: 1) was used as starter.

2. Stock culture of Aeromonas hydrophilla was prepared in alkaline peptone water. 


\section{B) Treatment:}

Yoghurt was manufactured by the method of Robinson and Tamino (1983) as follows: Raw cow's milk for yoghurt manufacture was pasteurized at $63^{\circ} \mathrm{C}$ for $30 \mathrm{~min}$., cooled to $10^{\circ} \mathrm{C}$ within $30 \mathrm{~min}$., then inoculated with the yoghurt culture (2\%) and mixed thoroughly. Two batches of yoghurt were prepared; one batch was used as control and the other was inoculated with the test organism to provide an inoculum level of $4 \times 10^{7}$ / $\mathrm{ml}$ milk.Both batches were kept at $4^{\circ} \mathrm{C}$.Samples were taken from the curd and then after $24 \mathrm{~h}$ till96h after curd formation and measured for $\mathrm{pH}$ value and Aeromonas hydrophilla counts.

\section{DISCUSSION}

The results given in Table(1) show that the acidity of raw milk samples tested were within the normal limits which ranged from 0.11 to 0.19 with a mean value of $0.15 \pm 0.021$.

Aeromonads were identified in $12 \%$ of milk samples using enrichment broth medium. Only $8 \%$ of the milk samples were positive using direct plate surface technique and showing colony counts varying from $1 \times 10^{5}$ to $4 \times 10^{5} \mathrm{CFU} / \mathrm{ml}$ with an average value of $2.5 \times 10^{5} \mathrm{CFU} / \mathrm{ml}$.(Table $2 \& 3$ ).

Nearly similar results could be detected by Enas (1999) while Moustafa (2000) found higher incidence.

Aeromonads are commonly present in farm (feed, water, soil, and equipments used for milking) and can thus contaminate the surface of udder, teats and get into milk. Hence the role of raw milk as a vehicle of transmission causing milk borne disease is well documented (Varnam and Evans, 1991).

$4 \%$ of milk samples were contaminated with A.hydrophila,A.caviae and $A$. janda while $8 \%$ of the samples were contaminated with A. trota (Table 5). Of 28 confirmed cultures isolated from raw milk, 14(50\%) of the strains could be classified as $A$. trota followed by $10(35.8 \%)$ as $A$. hydrophilia and $2(7.1 \%)$ as A. caviae and A. janda (Table 6). 
Higher results could be detected by Hussein (1999) and Moustafa (2000).

The results reported in Table(1)indicate that the $\mathrm{pH}$ values in examined yoghurt samples ranged from 3.70 to 4.25 with a mean value of 4.01 +0.03 .

The revealed results in Table (2 and 3) showed that Aeromonas spp. could be detected in $11(44 \%)$ of the examined yoghurt samples in counts ranged from $1 \times 10^{2}$ to $3.5 \times 10^{5}$ with a mean value of $4 \times 10^{4}+3 \times 10^{4}$. Lower incidence could be reported by Sami(1999)and El-Shorbagy and Al-Ganzoury (2002).

There is a marked decrease in the count of Aeromonas spp. as the $\mathrm{pH}$ value of the examined yoghurt sample decrease, the highest count 3.5 x $10^{5}$ was at $\mathrm{pH}$ value of 4.25 while the lowest count $1 \times 10^{2}$ was at $\mathrm{pH}$ value of 3.81 (Table 4). This is in agreement with Aykut Aytac and Yesim Özbas (1994).

The low $\mathrm{pH}$ value of yoghurt creates an undesirable environment for the growth of most spoilage microorganisms, where Aeromonas spp. are reported to be sensitive for $\mathrm{pH}$ value below 6.0. On the other hand, starter bacteria can produce diacetyl which had some bactericidal activity against Aeromonas (Plumbo and Buchanan, 1988; Motlagh et al.,1991and Varnam and Evans, 1991).

Each of A. hydrophila and A. coviae could be isolated from 6 (24\%) examined yoghurt samples followed by A. sobria 3 (12\%), A. trota $2(8 \%)$ and $A$. schuberttii 1 (4\%) (Table 5). Of 74 cultures isolated from yoghurt samples, $37.8 \%$ could be classified as A. caviae, $32.5 \%$ as A. hydrophila, each of A. sobria and A. trota by $13.5 \%$ and $2.7 \% A$. schuberttii (Table 6). Higher results could be detected by Enas (1999) and El-Shorbagy and Al-Ganzoury (2002).

The results obtained in Table (1) show that sodium chloride percent in cooking butter ranged from $0.5-1 \%$ with a mean value $0.9 \pm 0.03$. 
Aeromonads were detected in $36 \%$ of cooking butter samples examined by direct technique with count ranged from $1 \times 10^{3}$ to $6.1 \times 10^{4} \mathrm{cfu} / \mathrm{g}$ and with a mean value of $1.4 \times 10^{4} \pm 6.2 \times 10^{3}$ c.f.u/g (Table 2), while the incidence was $48 \%$ of examined samples after enrichment (Table 3 ).

From the results of analysis, it is noticed that there was no relation between the incidence of Aeromonas spp. and $\mathrm{NaCl} \%$ of samples as the $\mathrm{NaCl} \%$ is less than the legal requirement of $\mathrm{NaCl} \%$ for cooking butter 3\% according to the Egyptian standard (1976).

The lower recovery with direct method than with enrichment was explained by MacRae et al. (1993) who reported that Aeromonads can be inhibited by microorganisms present in the same sample because Aeromonads are poor competitor.

A.caviae was detected in 6(24\%)samples followed by A.hydrophila $4(16 \%)$ and A. trota 1 (4\%) of 46 Aeromonas isolates $56.5 \%$ were identified as A. caviae, 39.1 A. hydrophila and $4.4 \%$ A. trota.

Lower results could be detected by Abd El-Hady and Halawa (1999), while higher results were reported by Hussein (1999).

High incidence of Aeromonas in cooking butter may be a consequence of contaminated milk as the cooking butter is made from raw sower cream which produced under unsanitary conditions (Palumbo, 1987).

Regarding to Table (7 and Fig. 1) Aeromonas hydrophila failed to be detected in yoghurt after $72 \mathrm{~h}$ of storage at refrigeration temperature. Their count decreased from $4 \times 10^{7}$ to 0 parallel to decrease in $\mathrm{pH}$ value from 5.7 to 3.9. These results are supported by Aykut Aytac and Yesim $\ddot{O}_{z b a s}$ (1994) who stated that A. hydrophila was completely inhibited in control and acidophilus yoghurt after 5 days of storage.

So the $\mathrm{pH}$ of yoghurt can be used to control the growth of A. hydrophila. 
Incidence Of Aeromonas Species In Raw Milk And Some Dairy ...

In conclusion, selection of high quality raw milk and the importance of way of processing as well as the storage condition of dairy products on its final hygienic status, which may enhance or inhibit the microbial contaminants present.So selling of dairy product should be strictly controlled with health authority to eliminate potentiality of occurring hazards arising from microbial contamination.

Table (1): Statistical analytical results of sanitary tests and $\mathrm{NaCl}$ content in examined samples.

\begin{tabular}{|c|c|c|c|}
\hline Type of test & Min. & Max. & Mean \pm S.E.M. \\
\hline Titratable acidity of raw milk & 0.11 & 0.19 & $0.15 \pm 0.021$ \\
\hline $\mathrm{pH}$ value of yoghurt & 3.70 & 4.25 & $4.01 \pm 0.03$ \\
\hline $\mathrm{NaCl} \%$ of Butter & 0.5 & 1 & $0.9 \pm 0.03$ \\
\hline
\end{tabular}

- N.B. No. of examined sample 25 each.

Table (2): Statistical analytical results of Aeromonas spp. in examined samples using direct plate surface technique.

\begin{tabular}{|c|c|c|c|c|c|c|}
\hline \multirow{2}{*}{ Type of test } & \multirow{2}{*}{$\begin{array}{c}\text { No. of } \\
\text { examined } \\
\text { samples }\end{array}$} & \multicolumn{2}{|c|}{ +ve sample } & \multicolumn{3}{|c|}{ Count/ml or g } \\
\hline & & No. & $\%$ & Min. & Max. & Mean \pm SE \\
\hline & 25 & 2 & 8 & $1 \times 10^{5}$ & $4 \times 10^{5}$ & $2.5 \times 10^{5} \pm 1.1 \times 10^{5}$ \\
\hline Yoghurt & 25 & 11 & 44 & $1 \times 10^{2}$ & $3.5 \times 10^{5}$ & $4 \times 10^{4} \pm 3 \times 10^{4}$ \\
\hline Cooking butter & 25 & 9 & 36 & $1 \times 10^{3}$ & $6.1 \times 10^{4}$ & $1.4 \times 10^{4} \pm 6.2 \times 10^{3}$ \\
\hline
\end{tabular}

Table (3):Prevalence of Aeromonas spp.in examined samples using enrichment broth medium.

\begin{tabular}{|l||c||c|c|}
\hline \multirow{2}{*}{ Types of samples } & \multirow{2}{*}{$\begin{array}{c}\text { No. of examined } \\
\text { samples }\end{array}$} & \multicolumn{2}{|c|}{ Frequency } \\
\cline { 2 - 4 } & +ve samples & \% \\
\hline \multirow{2}{*}{ Raw milk } & 25 & 3 & 12 \\
\hline Yoghurt & 25 & 11 & 44 \\
\hline Cooking butter & 25 & 12 & 48 \\
\cline { 2 - 4 } & & & \\
\hline
\end{tabular}

Kafr El-Sheikh Vet. Med. J. Vol. 3 No. 1 (2005) 
Table (4): Relation between $\mathrm{pH}$ values and count of Aeromonas spp.in positive yoghurt samples.

\begin{tabular}{|c||c|}
\hline pH value & Count CFU/g \\
\hline \hline 4.25 & $3.5 \times 10^{5}$ \\
4.20 & $7 \times 10^{4}$ \\
4.16 & $5.9 \times 10^{3}$ \\
4.16 & $5.9 \times 10^{3}$ \\
4.11 & $5 \times 10^{3}$ \\
4.06 & $2.7 \times 10^{3}$ \\
4.05 & $1 \times 10^{2}$ \\
3.98 & $1 \times 10^{2}$ \\
3.96 & $1 \times 10^{2}$ \\
3.92 & $1 \times 10^{2}$ \\
3.81 & $1 \times 10^{2}$ \\
\hline
\end{tabular}

Table (5): Incidence of different motile Aeromonas spp. in dairy products analysed.

\begin{tabular}{|c|c|c|c|c|c|c|c|c|c|c|c|c|c|}
\hline \multirow{3}{*}{ Type of samples } & \multirow{3}{*}{$\begin{array}{c}\text { No. of } \\
\text { examined } \\
\text { samples }\end{array}$} & \multicolumn{12}{|c|}{ No. of samples with } \\
\hline & & \multicolumn{2}{|c|}{$\begin{array}{c}A . \\
\text { hydrophilia }\end{array}$} & \multicolumn{2}{|c|}{$\begin{array}{c}\text { A. } \\
\text { caviae }\end{array}$} & \multicolumn{2}{|c|}{$\begin{array}{c}\text { A. } \\
\text { sobria }\end{array}$} & \multicolumn{2}{|c|}{$\begin{array}{c}\text { A. } \\
\text { trota }\end{array}$} & \multicolumn{2}{|c|}{$\begin{array}{c}A . \\
\text { janda }\end{array}$} & \multicolumn{2}{|c|}{$\begin{array}{c}A . \\
\text { schubertii }\end{array}$} \\
\hline & & No. & $\%$ & No. & $\%$ & No. & $\%$ & No. & $\%$ & No. & $\%$ & No. & $\%$ \\
\hline iw milk & 25 & 1 & 4 & 1 & 4 & 0 & 0 & 2 & 8 & 1 & 4 & 0 & 0 \\
\hline Yoghu & 25 & 6 & 24 & 6 & 24 & 3 & 12 & 2 & 8 & 0 & 0 & 1 & 4 \\
\hline Cooking butter & 25 & 4 & 16 & 6 & 24 & 0 & 0 & 1 & 4 & 0 & 0 & 0 & 0 \\
\hline
\end{tabular}

Table (6): Frequency distribution of isolated Aeromonas spp. from examined dairy products.

\begin{tabular}{|c|c|c|c|c|c|c|c|c|c|c|c|c|c|}
\hline \multirow{3}{*}{$\begin{array}{l}\text { Type of } \\
\text { samples }\end{array}$} & \multirow{3}{*}{$\begin{array}{l}\text { No. of } \\
\text { isolates }\end{array}$} & \multicolumn{12}{|c|}{ No. of samples with } \\
\hline & & \multicolumn{2}{|c|}{$\begin{array}{c}A . \\
\text { hydrophilia }\end{array}$} & \multicolumn{2}{|c|}{$\begin{array}{c}\text { A. } \\
\text { caviae }\end{array}$} & \multicolumn{2}{|c|}{$\begin{array}{c}A . \\
\text { sobria }\end{array}$} & \multicolumn{2}{|c|}{$\begin{array}{c}A . \\
\text { trota }\end{array}$} & \multicolumn{2}{|c|}{$\begin{array}{c}\text { A. } \\
\text { janda }\end{array}$} & \multicolumn{2}{|c|}{$\begin{array}{c}A . \\
\text { schubertii }\end{array}$} \\
\hline & & No. & $\%$ & No. & $\%$ & No. & $\%$ & No. & $\%$ & No. & $\%$ & No. & $\%$ \\
\hline Raw milk & 28 & 10 & 35.8 & 2 & 7.1 & 0 & 0 & 14 & 50 & 2 & 7.1 & 0 & 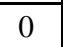 \\
\hline Yoghurt & 74 & 24 & 32.5 & 28 & 37.8 & 10 & 13.5 & 10 & 13.5 & 0 & 0 & 2 & 2.7 \\
\hline Cooking butter & 46 & 18 & 39.1 & 26 & 56.5 & 0 & 0 & 2 & 4.4 & 0 & 0 & 0 & 0 \\
\hline
\end{tabular}

Kafr El-Sheikh Vet. Med. J. Vol. 3 No. 1 (2005) 
Table (7): Effect of storage and $\mathrm{pH}$-value in the survival of Aeromonas hydrophila in yoghurt.

\begin{tabular}{|c||c||c|}
\hline Storage $(\mathbf{h})$ & pH & Count c.f.u/g \\
\hline \hline Initial count & 6.2 & $4 \times 10^{7}$ \\
Curd & 5.7 & $8 \times 10^{7}$ \\
$24 \mathrm{~h}$ & 5.0 & $1 \times 10^{6}$ \\
$48 \mathrm{~h}$ & 4.5 & $7 \times 10^{3}$ \\
$72 \mathrm{~h}$ & 4.2 & $5 \times 10$ \\
$96 \mathrm{~h}$ & 3.9 & 0 \\
\hline
\end{tabular}

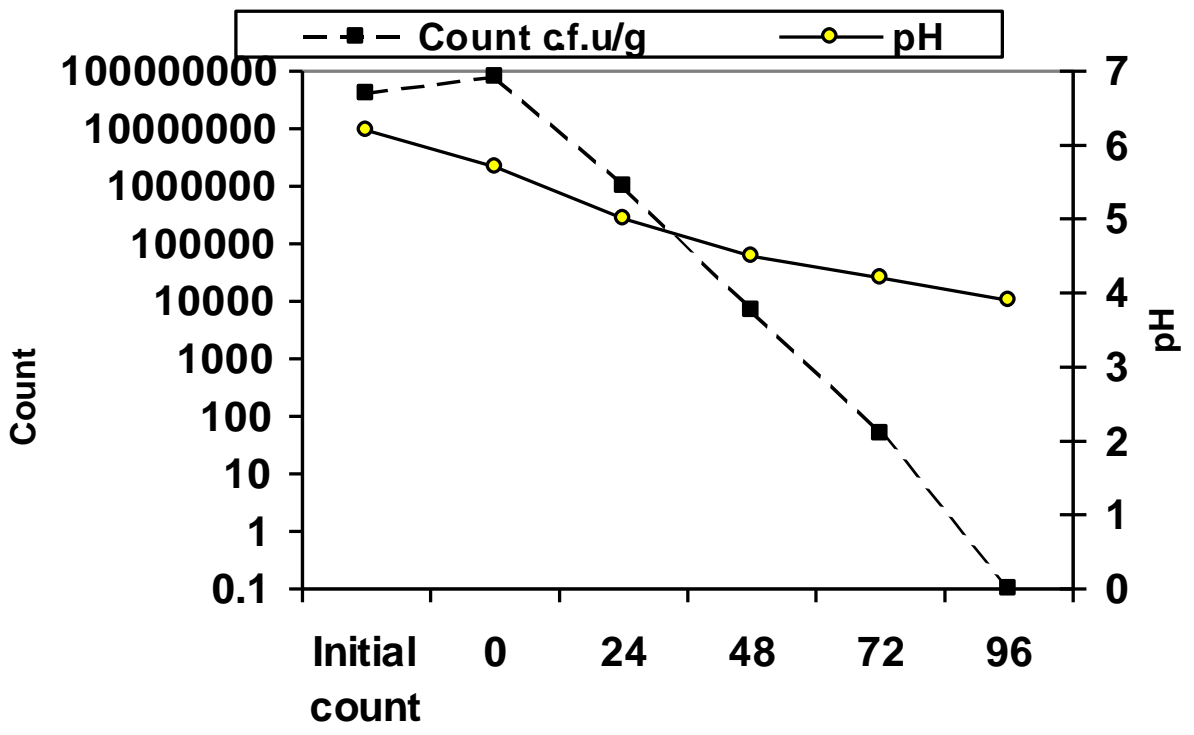

Fig. (1): Effect of storage and $\mathrm{pH}$ value on the survival of $A$. hydrophila in yoghurt.

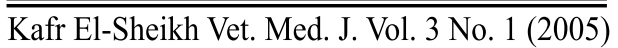




\section{REFERENCES}

- Abd El-Hady,H.M. and Halawa, M.A. (1999): Surveillance of Aeromonas and Listeria species in some dairy products. J. Egypt. Vet. Mod. Ass. 59(6): 1661-1670.

- American Public Health Association "A.P.H.A." (1985): Standard methods for the examination of dairy products. $15^{\text {th }}$ ed., New York.

- American Public Health Association "APHA" (1992): Compendium of methods for the microbiological examination of foods $3^{\text {rd }}$ ed. Washington, DC, USA.

- Aykut Aytac, S. and Yesim Özbas, Z. (1994): Growth of Yersinia enterocolitica and Aeromonas hydrophila in acidophilus yoghurt. The Australian J. Dairy Technology, Vol 49, Nov. 1994.

- Beuchat, L.R. (1991): Behaviour of Aeromonas species at refrigeration temperatures. Int. J. Food Microbiol. 13: 217-224.

- El-Shorbagy,I.M. and Al-Ganzoury,H.H. (2002): Incidence of Aeromonas species in raw milk and yoghurt in Zagazig city. J. Egypt. Vet. Med. Ass. 62 (4): 229-233.

- Enas,M.S.(1999): Prevalence of Aeromonas species in Sharkia Governorate M.V.Sc., Zagazig University, Egypt.

- Freitas, A.C.; Nunes, M.P.; Milhomem, A.M. and Ricciardi, I.D. (1993): Occurrence and characterization of Aeromonas species in pasteurized milk and white cheese in Rio de Janerio, Brazil. J. food Protect. 56: 62-65.

- Hussein, M.F. (1999): Occurrence of Aeromonas hydrophila in milk and some dairy products in Assiut City. M.V.Sc. Thesis, Fac. Vet. Med. Assiut University.

- International Standard Iso(1738-1980):Butter-determination of salt content (reference method) Iso, Geneva, Switzerland. 
- Janda, J.M. (1991): Recent advances in the study of the taxonomy, pathog-enicity,and infectious syndromes associated with the genus Aeromonas.Clin. Microbiol. Rev. 4: 397.

- Janda, J.M. and Duffey, P.S. (1988): Mesophillic aeromonads in human disease: current taxonomy, laboratory identification, and infectious disease spectrum. Rev. Infect. Dis. 10: 980.

- Khalil, N.G. (1997): Incidence of Aeromonas hydrophila group in raw milk and some dairy products in Assiut City. Assiut Vet. Med. J. 37: 100-108.

- MacRae, R.; Robinson, R.K. and Sadler, M.J. (1993): In encyclopedia of food science and food technology and nutrition. Harcout Biace Jovanoich Publishers London, New York.

- Motlagh, A.M.; Johnson, M.C. and Ray, B. (1991): Viability loss of food borne pathogens by starter culture metabolites.J.Food Prot., 54(11): 837-878.

- Moustafa, A.H. (2000): Prevalence of Aeromonas species in milk and some dairy products in Dakahlia Governorate. Ph.D. Vet. Med., Tanta University, Egypt.

- Palumbo, S.A. (1987): Can refrigeration keep our foods safe? Dairy \& Food Sanitation, 7: 56-60.

- Palumbo, S.A. and Buchanan, R.L. (1988): Factors affecting growth or survival of Aeromonas hydrophila in foods. J. Food Safety, 9: 37-51.

- Popoff, M. (1984): Aeromonas. In Bergey's Manual of Systemic Bacteriology, Vol. 1, (N.R. Krieg and J.G. Holt, ed.) pp. 545-548, Williams and Wilkins Co., Baltimore, MD.

- Robinson, R.K. and Tamine, A.Y. (1983): Microbiology of fermented milks: In dairy microbiology. Vol. 2. R.K. Robinson (ed.), App. Sci. Ltd., London.

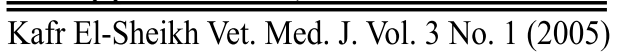


- Sami, E.M. (1999): Prevalence of Aeromonas spp. in milk and some dairy products in Sharkia Governorate. M.V.Sc. Thesis Fac. Vet. Med. Zagazig Univ.

- Varnam, A.H. and Evans, M.G. (1991): Food borne pathogens. Wolfe Publishing Ltd., London.

$$
\begin{aligned}
& \text { مدى نو اجد ميكروب الايروموناس فى الحليب الخام وبعض منتجات الألبان فى مدينة } \\
& \text { كفر الثيخ } \\
& \text { ونمو ميكروب الايروموناس هيدروفيلا فى الزبادى } \\
& \text { عزه مرغنى محمد ديب }
\end{aligned}
$$

قسم مراقبة الأغذية ـ كلية الطب البيطرى بكفرالثيخ ـ جامعة طنطا

تم تجميع 75 عينة من الحليب الخام ، الزبادى وزبد الطبخ (25 من كل منتج) من أماكن مختلفة من أسواق مدينة كفر الثيخ لفحصها لمدى نواجد ميكروبات الايروموناس. وقد نم عزل ميكروبات الايروموناس من 8\% ، 44\% ، 36\% من الحليب الخام ، الزبادى وزبد الطبخ باستخدام الفرد السطحى على المستتبت بينما تم عزلها بنسبة 12\% ، 44\% ، 48\% باستخدام طريقة الإنماء الغير مباشر فى عينات الحليب الخام ، الزبادى وزبد الطبخ.

تبين من النتائج أن ميكروب الايروموناس هيدروفيلا نم عزله من 4 ، 24 ، 16\% من

الحليب الخام ، الزبادى وزبد الطبخ ، أما بالنسبه لميكروب الايروموناس كافى فقد نم عزله بنسبة 4 ، 24 ، 24\% من نفس العينات على التوالى وبالنسبه لميكروب الايروموناس سوبريا فقد تم عزله من عينات الزبادى فقط بنسبة 12\% وقد نم عزل ميكروب الايروموناس نروتا من 8\% من كل من عينات الحليب الخام والزبادى وبنسبة 4\% من عينات الزبد أما بالنسبة لميكروب الايروموناس جاندا فقد تم عزله من الحليب الخام فقط بنسبة 4\% وأخيرا ميكروب الايروموناس سكبرتى فقد تم عزله من الزبادى فقط بنسبة 4\%. 
هذا وقد تم دراسة تأثير تركيز أيون الهيدروجين pH فى الزبادى على نمو ميكروب الايروموناس هيدروفيلا مع حفظ المنتج فى درجة حرارة الثلاجة وقد وجد أن pH لها تأثير فعال على تهى نمو هذا الميكروب وكلما تناقص تركيز أيون الهيدروجين تتاقص عدد هذا الميكروب حتى اختفى بعد 96 ساعة من الحقن وعند تركيز 3.9 pH

وقد تمت مناقثة الأهمية الصحية لوجود تلك الميكروبات فى منتجات الألبان تحت الدراسة. 